\title{
Sandy braidplan deposits from the Triassic Skagerrak Formation in the Thisted-2 well, Denmark
}

BY

HENRIK OLSEN

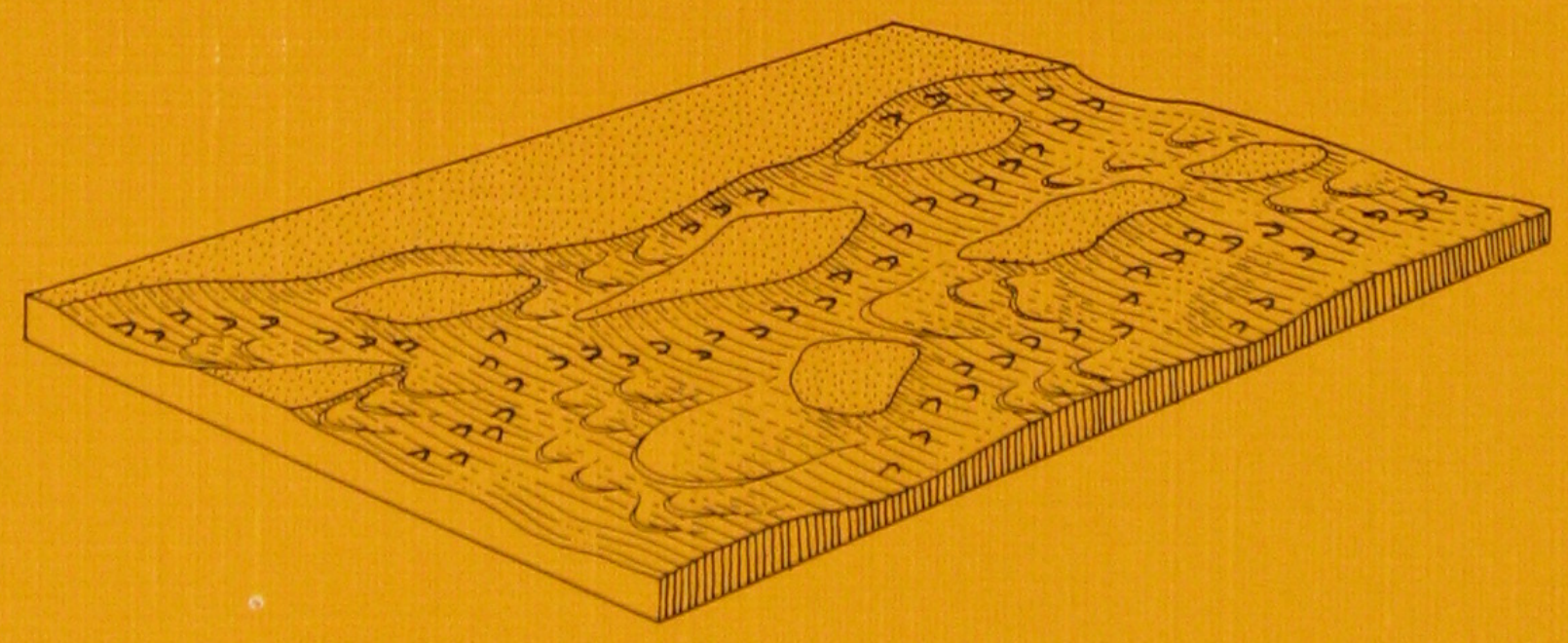

I kommission hos C. A. Reitzels Forlag · København 1988 


\section{Sandy braidplan deposits from the Triassic Skagerrak Formation in the Thisted-2 well, Denmark}

BY

HENRIK OLSEN 
Key-words:

Lithology, sandstone,

depositional environment,

Triassic, Denmark

with a folded well log

Vignette:

Reconstruction of a type of braidplain environment

DGU $\cdot$ Serie B. - nr. 11

ISBN 87-421-0756-3

ISSN 0901-0289

Oplag: 1000

Tryk: AiO Tryk as, Odense

Tegning: Rene Madsen

Dato: $15-9-1988$

Henrik Olsen

Geological Survey of Greenland, Øster Voldgade 10, DK-1350 Copenhagen K,

Denmark

Redaktion: Leif Banke Rasmussen

(C) Danmarks Geologiske Unders $ø$ gelse,

Thoravej 8, DK-2400 København NV. 


\section{Contents}

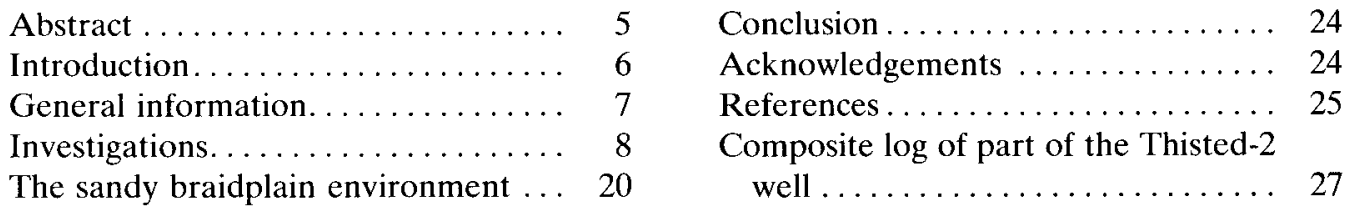




\section{Abstract}

Detailed facies analyses have been carried out on the Triassic Skagerrak Formation on core material from the Thisted-2 well, Denmark. Facies patterns in the sediments show affinity to present day river models. The informations are combined into a braidplain model in which the proximal braidplain was composed of featureless Platte-type streams. Deeper South Saskatchewan-type streams represented the intermediate braidplain. The distal braidplain was dominated by ephemeral streams. Towards north and northeast coalescing alluvial fans formed the immediate connection to the sourcearea, the Fennoscandian Shield. 


\section{Introduction}

The Triassic Skagerrak Formation is defined by Deegan \& Scull (1977) on basis of petrophysical logs. The type section is the Norwegian well 10/8-1 in which the Skagerrak Formation is composed of interbedded sandstones, conglomerates and mudstones. The reference section (Norwegian well 17/10-1) is dominated by sandstones. Further information on the lithology of the Skagerrak Formation within the Norwegian-Danish Basin has been presented by Berthelsen (1980), Jacobsen (1980) and Pedersen \& Andersen (1980).

The depositional environment of the Skagerrak Formation was a continental alluvial plain with deposition of interbedded sandstones, conglomerates and mudstones on marginal alluvial fans (Deegan \& Scull 1977). Downstream the alluvial fans were replaced by sandy braided streams forming huge braidplains (Pedersen \& Andersen 1980). The sandy braidplain deposits have previously been referred to as Bunter Sandstone Formation (Pedersen \& Andersen 1980) and transitional to Skagerrak Formation (Berthelsen 1980). Nielsen (1982) and Frandsen (1983) conclude, however, that the sandy braidplain deposits should be referred to as Skagerrak Formation. 


\section{General}

The Thisted- 2 well is located on the southern flank of the Thisted salt pillow in northern Jutland, Denmark (Fig. 1). The top of the Skagerrak Formation was penetrated at a depth of $1598.4 \mathrm{~m}$ (below rotary table). Total depth of $3287.3 \mathrm{~m}$ was reached in the Skagerrak Formation without penetrating it. The top of the formation is defined by the change from dominantly claystones and mudstones typical of the Oddesund Formation, to interbedded sandstones and mudstones that characterize the upper part of the Skagerrak Formation (Nielsen 1982,
Frandsen 1983). This upper part extends to a depth of $2666 \mathrm{~m}$. Below $2666 \mathrm{~m}$ sandstones with only minor mudstone interbeds (Frandsen 1983) constitute the lower part of the Skagerrak Formation (Plate 1). Three cores were cut in the lower sandy part of the Skagerrak Formation at depths from 2760.5 $\mathrm{m}$ to $2766.2 \mathrm{~m}$, from $2907.6 \mathrm{~m}$ to $2925.5 \mathrm{~m}$ and from $3152.2 \mathrm{~m}$ to $3170.3 \mathrm{~m}$ (Plate 1). The core material is considered representative for the entire lower part of the Skagerrak Foramtion in the well, i.e. the interval from $2666 \mathrm{~m}$ to $3287 \mathrm{~m}$.

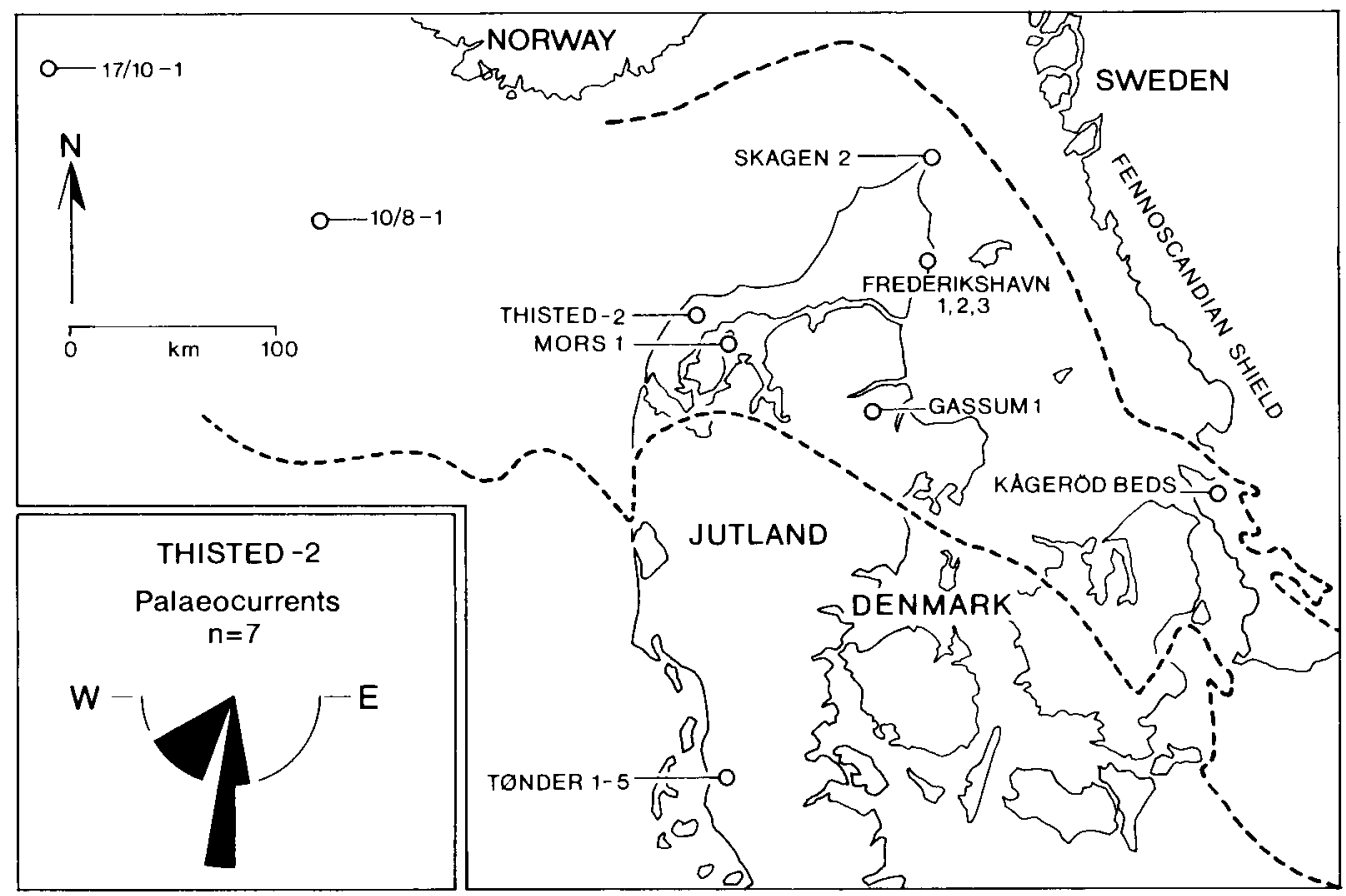

Fig. 1. Location map. Thisted-2 and other wells and localities mentioned in the text are shown. Palaeocurrents for Thisted-2 derived from dipmeter readings are indicated. The maximum extension of the Skagerrak Formation at present is shown by dashed lines, compiled from Bertelsen (1980). 


\section{Investigations}

The aim of the present study is a detailed investigation of sedimentary facies, processes and palaeoenvironments of the Triassic braidplains which laid down the unusually thick, apparently uniform sandy succession of the lower Skagerrak Formation.

The sediments from the three cores in Thisted- 2 consist predominantly of sandstones and classify as arkosic arenites. The sandstones are pale red, well sorted (Fig. 2) and dominantly large-scale cross-bedded. Dark red intraformational mud clasts abound throughout the sections, whereas in situ dark red mudstone layers are scarce.

Dipmeter-logging has been carried out and processed with search intervals of $1 \mathrm{~m}$, step length $0.5 \mathrm{~m}$ and search angle $45^{\circ}$. Careful correlation of the processed dipmeter-logs and the core material reveals seven reliable palaeocurrent readings from large-scale cross-sets (facies Sp). The palaeocurrents are consistently towards southsouthwest (Fig. 1) which is in agreement with the sediment transport directions sug-
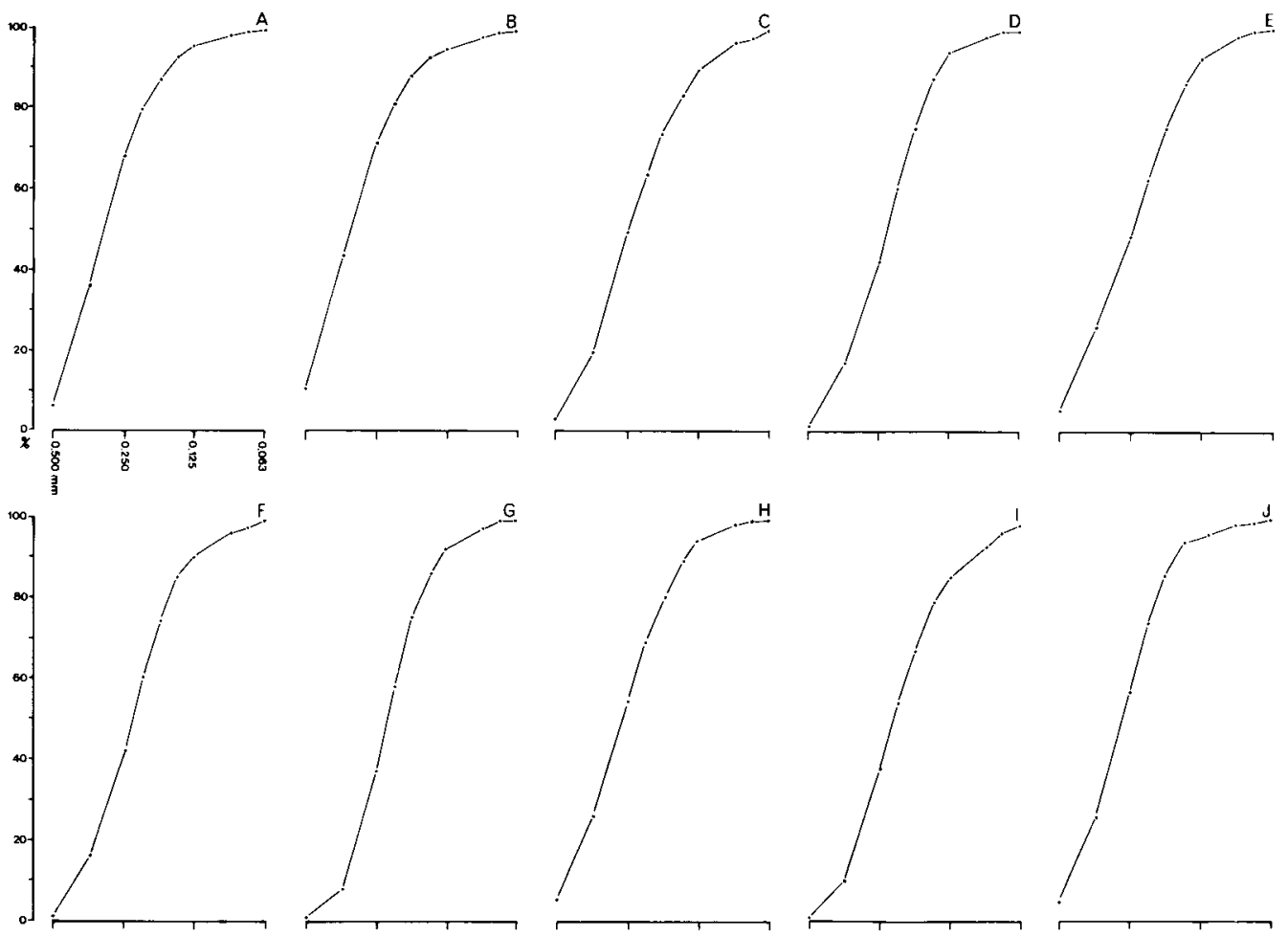

Fig. 2. Grain-size distribution (sieve analyses) in sandstone facies from the Skagerrak Formation. $(A-G)$ facies $S x,(H, I)$ facies $S t,(J)$ facies $S h / l$. The sandstones are generally well sorted. 
C

a

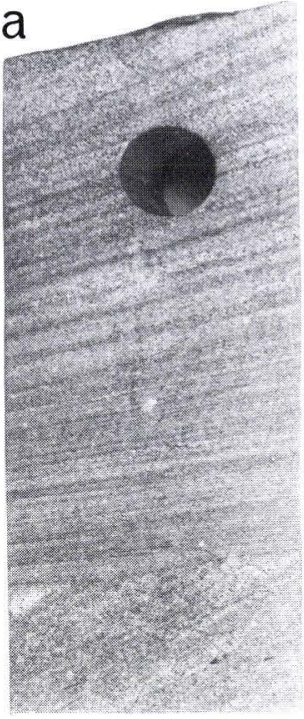

d

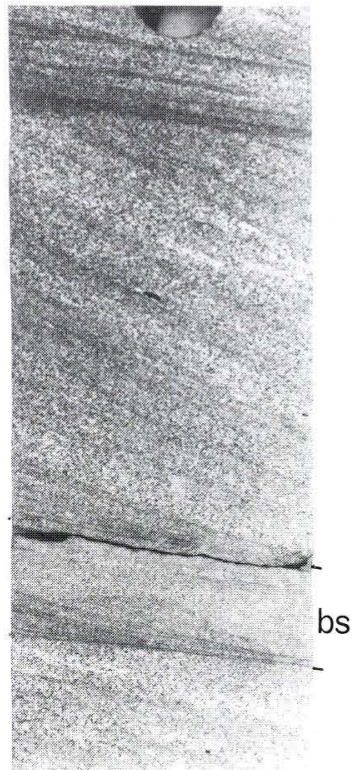

b

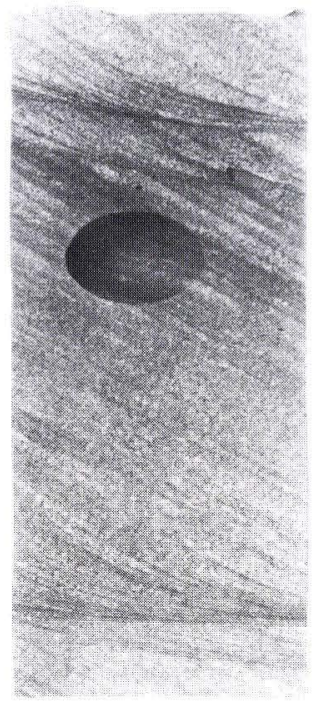

$10 \mathrm{~cm}$

e

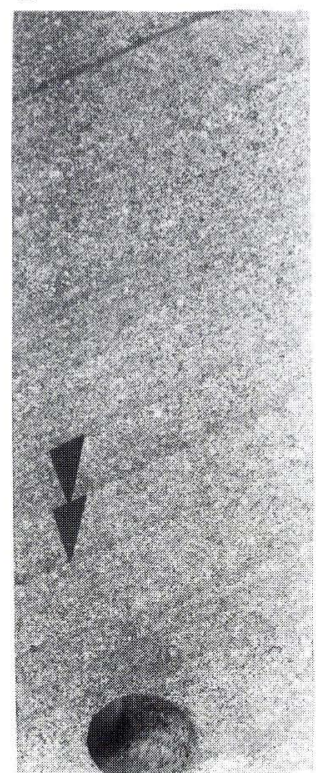

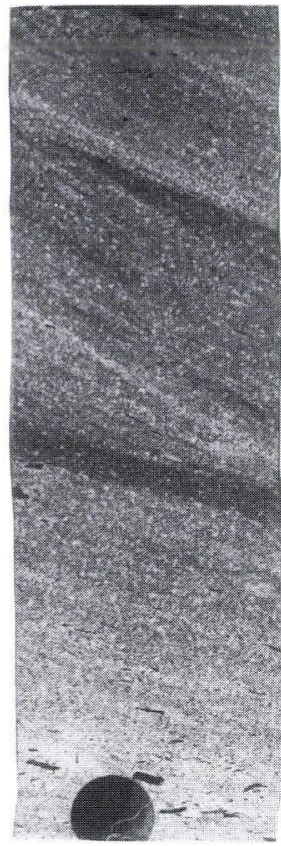

f

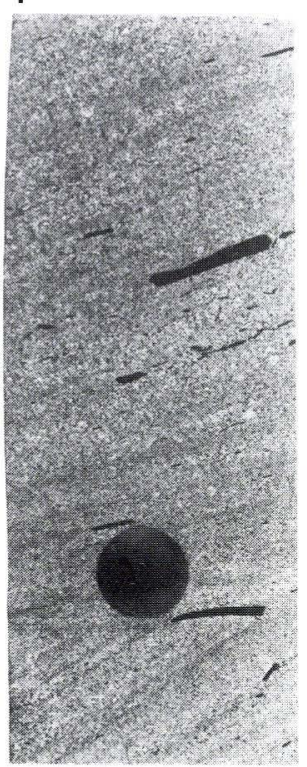

Fig. 3. Facies Sp, large-scale planar cross-bedded sandstones, interpreted as linguoid bar deposits. Tangentiality is seen as a downward flattening of foreset strata in the lower $10 \mathrm{~cm}$ (a) or the lower 2 $\mathrm{cm}(b)$ of the cross-set. Superimposed cross-laminated sets, facies $\mathrm{Sr}$, are seen in (b). (c) two internal discordancies in a cross-set, either formed during falling stage (cf. Jones 1977), or by reactivation (cf. Collinson 1970). (d) Sp cross-set with a finer grained bottomset (bs) composed of parallel lamination and cross-lamination. (e) a few inversely graded foreset strata (sandflows) in a Sp cross-set. (f) flat intraformational mudclasts aligned parallel to the foreset strata. 
gested by Pedersen \& Andersen (1980).

The investigation was carried out by detailed facies $\log$ analysis (scale 1:10) on well preserved core material from the Thisted-2 well. All dips presented below are entirely measured on the nonorientated cores. The regional dip is $5^{\circ}-8^{\circ}$ towards south-southeast.

\section{Facies}

Five facies types are recognized in the cored intervals. The facies are defined by primary sedimentary structures and lithology.

\section{Facies Sp: Large-scale planar cross- bedded sandstones}

\section{Description}

Large-scale cross-bedded sandstones with planar sets (Figs $3 \& 4$ ), is the most common facies type forming $51 \%$ of the rock volume (86 sets). The grain-size ranges from fine to coarse sand, most sets being fine- to medium-grained $(250 \mu \mathrm{m})$. Intraformational mudclasts occur in a large number of sets $(66 \%)$. The bases of individual sets are planar within the core diameter. The foresets are mainly tangential (87\%) or angular. Tangentiality is commonly observed as an upward change from base-parallel foresets (toesets) to steeply inclined foresets (max. $36^{\circ}$ ), see Fig. 3a. In $30 \%$ of all sets the $2-10$ $\mathrm{cm}$ thick toesets are finer grained than the main part of the set (inverse grading). Only $9 \%$ of all sets exhibit normal grading. In $13 \%$ of the cross-sets the lower $2-15 \mathrm{~cm}$ of the sets are sharply differentiated as bottomsets, composed of small-scale cross-lamination or parallel lamination (Fig. 3d). Individual foreset cross-strata are usually poorly defined. In less than $20 \%$ of the cross-sets well-defined $1 \mathrm{~mm}-30 \mathrm{~mm}$ thick cross-strata occur. The cross-strata are defined by variations in grain-size, usually within an order of one phi unit. About 5\% of the cross-sets exhibit a few normal graded

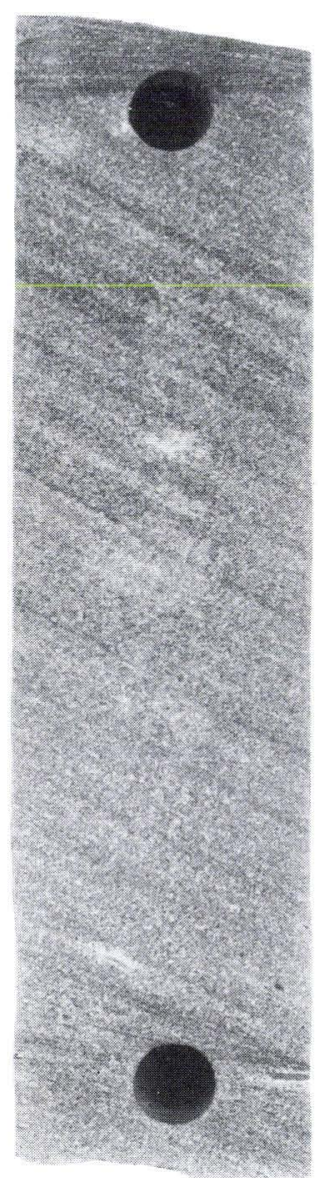

$10 \mathrm{~cm}$

Fig. 4. A thick large-scale planar cross-set, facies $S p$, interpreted as a linguoid bar deposit. Notice the straight character of the foreset strata and tangentiality, seen as a flattening of foreset strata in the lowermost part of the cross-set. A flat intraformational mudclast (lag deposit) is observed along the base of the set.

cross-strata, the grading occurring within one phi unit and in 1 cross-set inverse grading of cross-strata occurs (Fig. 3e). The thickness of individual cross-sets vary from $5 \mathrm{~cm}$ to $90 \mathrm{~cm}$ with a mean of $23 \mathrm{~cm}$. Facies Sp usually occurs as cosets with up to 13 sets and only $15 \%$ of the cross-sets are solitary sets. Five percent of all sets exhibit internal 
low-angle discordance surfaces inclined in the same direction as the cross-strata (Fig. $3 c)$. Palaeocurrent differences in superimposed cross-sets (Sp cosets) are very small (Fig. 5).

\section{Interpretation}

The planar set contacts, the thickness of individual cross-sets, the straight character of foreset strata, commonly with tangential toesets and small palaeocurrent variations in cosets point to an origin from straightcrested or linguoid mesoforms (sensu Jackson 1975). Straightcrested megaripples, linguoid bars, alternate bars and cross-channel bars are common braided stream mesoforms producing planar cross-sets (e.g. Collinson 1970, Smith 1970, Cant \& Walker 1978, Crowley 1983). The dominance of cosets indicates a repetitive mesoform. The most commonly occurring repetitive mesoforms in braided streams are linguoid bars, which are well described from the Tana River (Collinson 1970) and from the Platte River (Smith 1970, 1971, Blodgett \& Stanley 1980, Crowley 1983).

The dominance of tangential foresets in which the toesets are often finer grained, and the presence of bottomsets in several cross-sets probably indicate high velocities and high proportions of grainfall deposition on the leesides of the bars (cf. Jopling 1965). The poor definition of foreset crossstrata may also be explained by grainfall deposition or continuous avalanching which both imply high velocity and sediment transport (cf. Allen 1982, Hunter \& Kocurek 1986). Facies $\mathrm{Sp}$ is accordingly not of the same kind which Hunter (1985) described as typical subaqueous (fluvial) cross-bedding. Hunter's cross-strata, formed by intermittent sandflows, were well-defined, usually inversely graded and coarsening downdip, and foresets were mostly angular. The less common alternating coarser and finer crossstrata in facies Sp were probably formed by intermittent sandflows (coarser strata) and

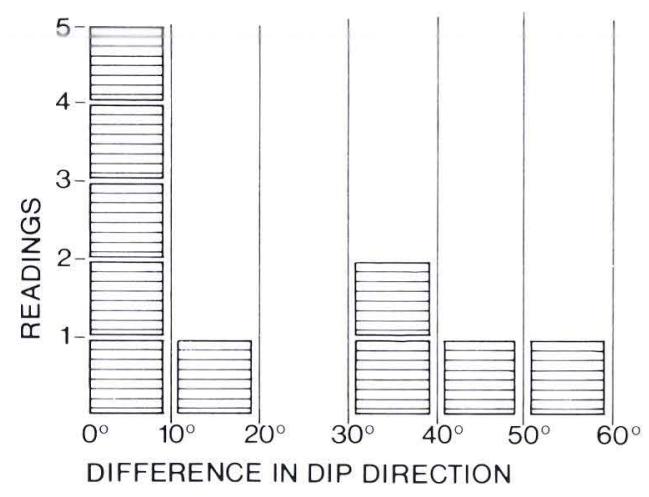

Fig. 5. Palaeocurrent differences in superimposed Sp cross-sets within cosets. The bulk of the readings lies in the interval $0^{\circ}-10^{\circ}$, indicating very small differences in migration direction of the bars.

grainfall (finer strata). Normal graded cross-strata may be explained by outracing of coarser grains by finer grains in sandflows (cf. Hunter 1985).

The thickness of individual sandflow cross-strata may reflect the height of the slipface (Hunter 1985, Hunter \& Kocurek 1986). By using the experimentally based relation between slipface height $(\mathrm{H})$ and slipface advance per sandflow $(\mathrm{Sa})(\mathrm{H}=$ $\mathrm{Sa}(0.060)^{-1}$; Hunter \& Kocurek 1986) and assuming an original maximum slipface dip angle of $30^{\circ}$, the height of the slipface can be estimated:

$$
\mathrm{H}=\left(\sin 30^{\circ}\right)^{-1}(0.060)^{-1} \mathrm{~T}=33.333 \mathrm{~T}
$$

where $\mathrm{T}$ is the thickness of an individual sandflow crossstratum. As the thickest sandflow stratum observed is $3 \mathrm{~cm}$ the maximum height of the bars were probably about $1 \mathrm{~m}$.

The internal discordances within some of the cross-sets resemble the type B and C erosion surfaces of Jones (1977). They may therefore suggest deposition during moderate to slow fall of discharge. Alternatively, these discordances may reflect the reactivation of a bar (cf. Collinson 1970) or overtaking by upcurrent bars during rapidly ris- 
a

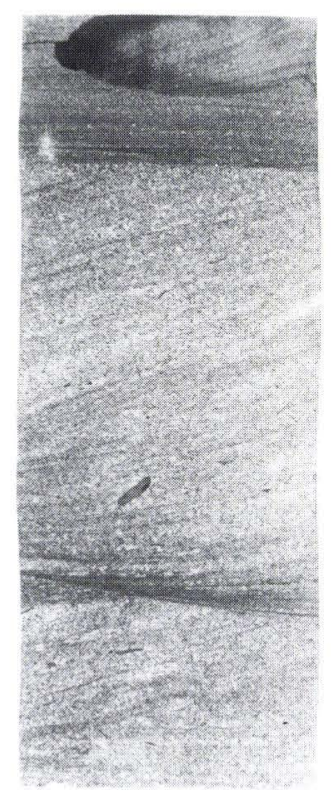

C

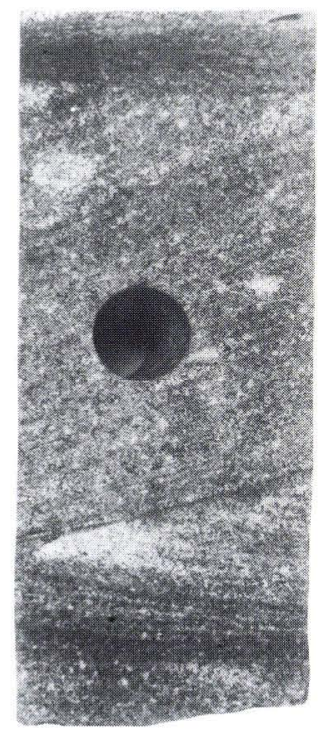

b

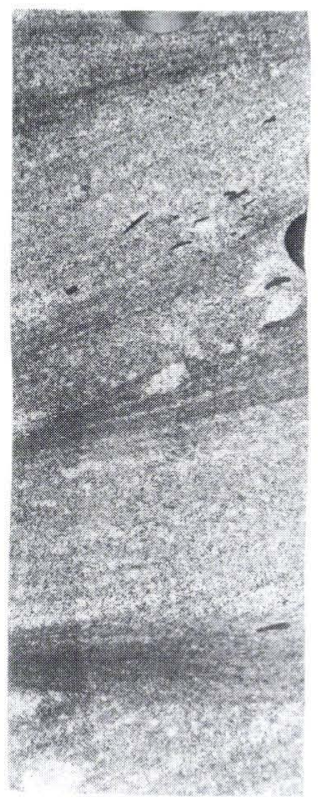

d

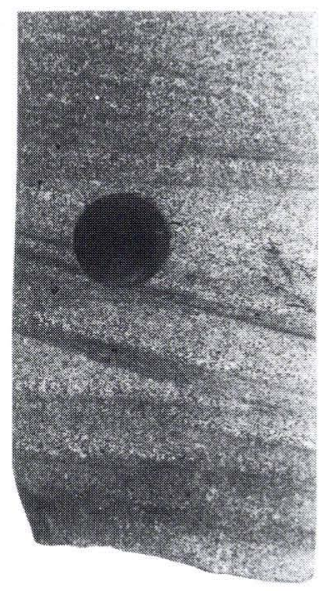

$10 \mathrm{~cm}$

Fig. 6. Facies St, large-scale trough cross-bedded sandstones, interpreted as lunate or sinuous-crested dune deposits. Notice the concave-up set contacts and foreset strata $(a, b, c)$. Superimposed cross-sets show major differences in the dip directions (c) reflecting the curved shape of the bedform leesides. (d) normal grading wedge-shaped crossstrata (sandflows). 
ing discharge (e.g. McGowen \& Groat 1971).

\section{Facies St: Large-scale trough cross- bedded sandstones}

\section{Description}

Large-scale trough cross-bedded sandstones (Fig. 6) form $22 \%$ of the cored intervals (95 sets). The grain-size is usually about 250 $\mu \mathrm{m}$, varying within the fine and medium sand classes. Intraformational mudclasts occur in a fair number of sets $(36 \%)$. The bases of individual sets are concave-up. The foresets are concave or, rarely, tangential and asymptotic to the base of individual sets. The maximum dip of foresets is generally less than $20^{\circ}$ with a rare maximum of $30^{\circ}$. Individual sets are nongraded with few exceptions $(5 \%$ inversely graded, $2 \%$ normal graded). Backflow crosslamination occurs in $4 \%$ of the sets. Individual crossstrata are usually poorly defined. In less than $20 \%$ of the sets well-defined $1 \mathrm{~mm}-20$ mm thick cross-strata occur, the figure being 1-5 mm thick. The well-defined crossstrata are defined by variations in grainsize, usually within an order of one phi unit. The coarser cross-strata are commonly wedgeshaped and occasionally normal graded (Fig. 6d). The thickness of individual crosssets varies from $4 \mathrm{~cm}$ to $28 \mathrm{~cm}$, averaging 9 $\mathrm{cm}$. Facies St almost exclusively occurs as cosets with up to 15 sets. Within the cosets the foreset dip directions always vary significantly, up to $90^{\circ}$.

\section{Interpretation}

The concave set contacts and foreset shape, the variation in foreset dip direction within cosets and the thickness of individual sets are indicatives of large-scale trough crossbedding. Cosets of trough cross-sets are typically formed by trains of sinuous-crested or lunate dunes (e.g. Harms et al. 1982). The mean thickness of the trough sets $(9 \mathrm{~cm})$ is smaller than the mean of planar set thickness $(23 \mathrm{~cm})$. Thus it is likely that the dunes were smaller bedforms than the linguoid bars. This interpretation is supported by the fact that the sandflow cross-strata in facies St are thinner ( $\max .20 \mathrm{~mm}$ ) compared with facies Sp $(\max .30 \mathrm{~mm})$. Following Hunter \& Kocurek (1986) and assuming an original maximum slipface dip angle of $30^{\circ}$, the maximum slipface height of the dunes reached $0.7 \mathrm{~m}$.

\section{Facies Sh/l: Parallel laminated sandstone}

\section{Description}

Deposits are referred to as facies Sh/l when the lamination in no part of a bed is steeper than $20^{\circ}$ and the lower contact is parallel to the succeeding lamination.

Parallel laminated sandstones (Fig. $7 a, b, c)$ form $15 \%$ of the deposits. The grainsize ranges from $50 \mu \mathrm{m}$ to $300 \mu \mathrm{m}$, most beds being very fine- to fine-grained. The sorting is good. The bases of beds are planar and even or slightly scoured. The bed thickness ranges between $2 \mathrm{~cm}$ and $255 \mathrm{~cm}$, the latter extreme rarely occurring. About $90 \%$ of $\mathrm{Sh} / \mathrm{l}$ beds are less than $20 \mathrm{~cm}$ thick. The lamination is distinct ( $95 \%$ of the beds) and composed of $0.1 \mathrm{~mm}-3 \mathrm{~mm}$ thick laminae (Fig. 8a). Continuous and discontinuous laminae usually alternate unsystematically within the beds though this feature may be a function of the small core diameter. No grading of individual laminae is apparent. The dip of laminae is constant within individual beds though an upward decrease in dip-angle is observed in three beds. In one of these three beds fining-upwards and a ripple form draped by the parallel lamination occur (Fig. 7c). Intraformational clasts occur in $30 \%$ of the beds, the concentration of clasts is, however, commonly less than $5 \%$.

One exceptionally thick bed $(255 \mathrm{~cm})$ is observed in core 3 . The true thickness is uncertain, because the bed constitutes the lowermost part of the core 3 interval. The 
b
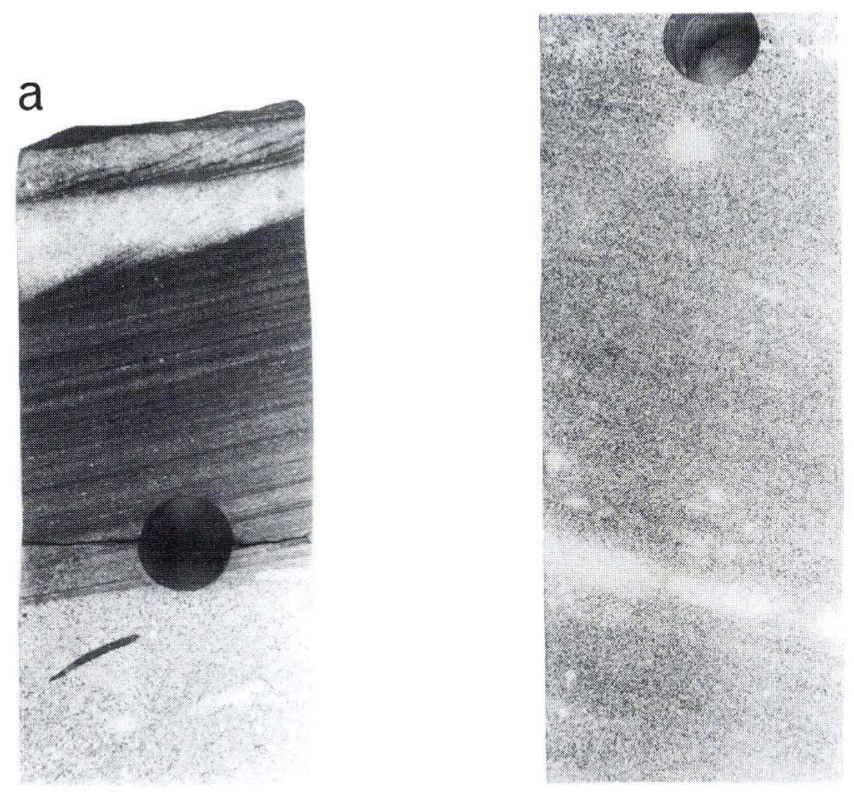

C

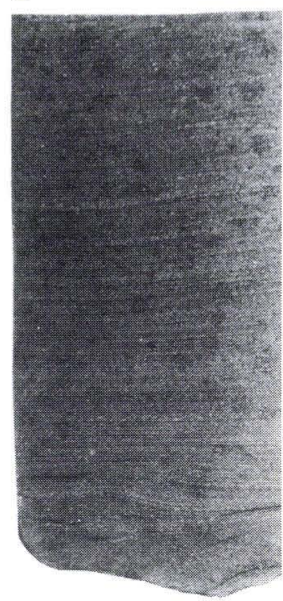

d

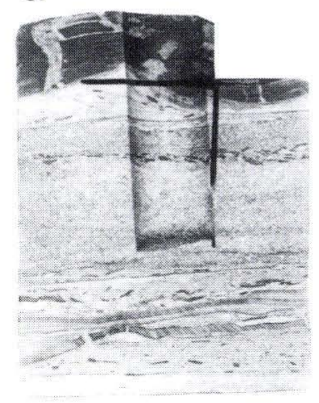

$10 \mathrm{~cm}$

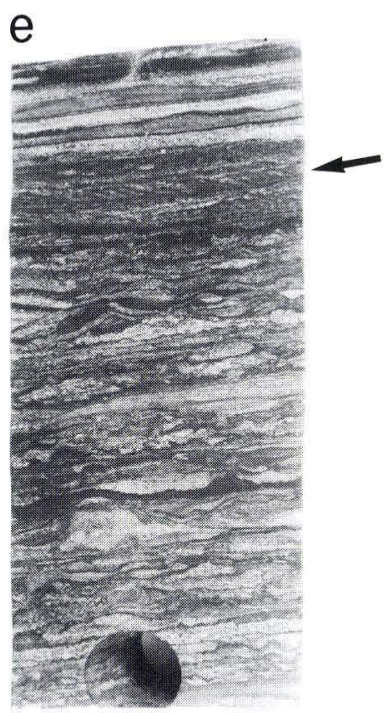

Fig. 7. Facies Sh/l, Sr and F. (a) distinctly parallel laminated sandstone (upper plane bed), facies Sh/l, overlain by cross-laminated sandstone, facies $S r$. (b) indistinctly parallel laminated sandstone (upper plane bed), facies Sh/l. (c) parallel lamination (suspension fall-out), facies Sh/l, draping a ripple formset, facies Sr. (d) heterolith, facies $F$, composed of parallel laminated and cross-laminated sandstones and mudstones with desiccation cracks. (e) irregular laminated heterolith, facies $F$. Pseudo-cross-lamination formed by climbing adhesion ripples is shown by arrow. Crinckly lamination (adhesion warts) and bi-directional cross-lamination (wave ripples) are also seen. The heterolith was deposited on the floodplain. 
lamination is ill-defined (Fig. 8b) and dips $7^{\circ}-18^{\circ}$. The dip direction is constant throughout the bed. The grain-size averages $300 \mu \mathrm{m}$ though the sorting is poor with a range from $100 \mu$ to $500 \mu \mathrm{m}$ throughout the bed.

\section{Interpretation}

Parallel lamination in very fine to mediumgrained sandstones has been attributed to several different mechanisms (e.g. Reineck \& Singh 1980). However, deposition on upper flow regime plane beds is favoured (e.g. Harms \& Fahnestock 1965, Bridge 1978, Cheel \& Middleton 1986). The abundant erosive bases of facies Sh/l beds and presence of intraformational clasts in several beds indicate an upper flow regime origin of the facies. The occurrences of upward decreasing dip-angles, associated with finingupwards and ripple-drapes in one bed, point to sedimentation of this bed from suspension clouds rather than traction mechanisms (cf. Gustavson et al. 1975). The measured dips of lamination in facies $\mathrm{Sh} / 1$, up to $20^{\circ}$, is considered partly to be a function of the regional dip. The regional dip is $5^{\circ}-8^{\circ}$ whereas the original depositional dip of the parallel lamination is interpreted to be less than $15^{\circ}$. The very thick parallel laminated sandstone bed in core 3 shows a dip in the same direction as the regional dip (both measured from dipmeter logs). The maximum depositional dip of the lamination in this bed accordingly was $10^{\circ}-13^{\circ}$.

\section{Facies Sr: Cross-laminated sandstones}

\section{Decription}

Cross-laminated sandstones (Fig. 3b, 7a,c) constitute $5 \%$ of the cored intervals. The grain-size range is very fine to medium sand and the sorting is generally good. The crosslamination occurs in unidirectional cosets of $1 \mathrm{~cm}$ to $3 \mathrm{~cm}$ thick wedge- and troughshaped sets. Occasionally formsets are pre- served (Fig. 7c). The foreset stratification is usually distinct and individual strata are 1 $\mathrm{mm}$ to $3 \mathrm{~mm}$ thick. The foresets are always concave. Intraformational clasts are rare.

\section{Interpretation}

The small wedge- to trough-shaped crosssets reflect deposition from migrating small sinuous-crested current ripples (e.g. Harms 1975). They are indicative of low energy currents, i.e. the lower part of lower flow regime.

\section{Facies F: Mudstones, siltstones and heteroliths}

\section{Description}

Mudstones, siltstones and heteroliths (Fig. $4 d, e)$ constitute only $4 \%$ of the cores. Thin solitary mudstone and siltstone beds are 1 $\mathrm{mm}$ to $10 \mathrm{~cm}$ thick and parallel laminated. In one of these beds desiccation cracks are observed. Three heterolithic intervals occur, ranging in thickness from $15 \mathrm{~cm}$ to 106 $\mathrm{cm}$. The heteroliths are characterized by very irregular thin beds ( $\mathrm{mm}$ to $\mathrm{cm}$ scale) and highly varied lamination types (Fig. $7 \mathrm{~d}, \mathrm{e})$. The sandy beds consist of unidirectional and bidirectional cross-lamination, parallel lamination, crinckly parallel lamination and pseudo-cross-lamination (cf. Hunter 1973) (Fig. 7e). The mudstones and siltstones occur as millimetre thick drapes or as intraformational clasts. Desiccation cracks are common (Fig. $7 \mathrm{~d}$ ).

\section{Interpretation}

Facies $\mathrm{F}$ represents the lowest energy level in the cored interval. Thin solitary mudstone and siltstone beds probably formed by suspension fall-out in temporarily abandoned channels. Desiccation cracks indicate complete drying out of the channels. The heterolithic intervals may also reflect aban- 


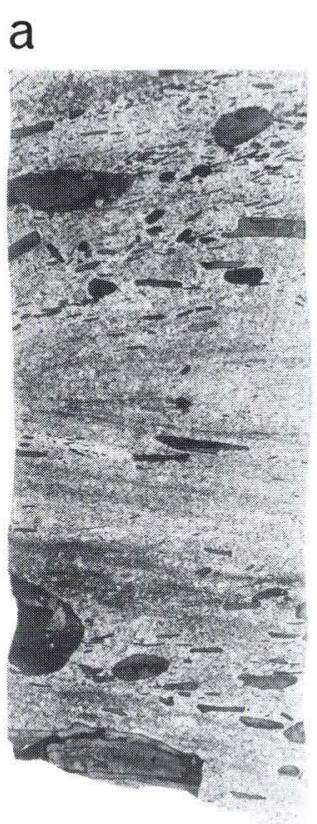

b

\section{$10 \mathrm{~cm}$}

Fig. 8. (a) intraformational clasts in large-scale trough cross-bedded sandstone (St). (b) deformed bedding in the upper part of a flood controlled depositional unit.

doned channels, inundated by several flood incursions. The $106 \mathrm{~cm}$ thick heterolith, in which crinckly lamination and indistinct pseudo-cross-lamination is observed (Fig. 7e) was, however, probably formed on a floodplain. When the floodplain was inundated parallel laminated and unidirectional crosslaminated sand was deposited. At recession of the floods muds and silts were deposited. These were ultimately desiccated upon drying out and were sometimes reworked by later floods. Wind activity resulted in wave motion in ponded areas of the floodplain and created wave ripples with bidirectional cross-lamination. When the wind blew across damp surfaces crinckly parallel lamination and pseudo-cross-lamination was formed by adhesion-warts and -ripples, respectively (cf. Hunter 1973, 1980, Kocurek \& Fielder 1982).

\section{Miscellaneous features}

Intraformational mud clasts abound in facies $\mathrm{Sx}$ and St (Fig. 8a). The clast size varies from $2 \mathrm{~mm}$ to a maximum of $8 \mathrm{~cm}$. The clasts are usually angular and flat (typical ratio 10:1) though rounded clast of more equant dimensions also occur. The clasts are usually aligned parallel to the foreset strata and scattered throughout a cross-set but also occur as lags. The abundance of intraclasts indicates that facies $F$ probably was more abundant in the depositional environment than actually noted. The preservation potential was, however, low.

Extraformational clasts are rare. Only six granule size granitic clasts of subangular to wellrounded character are observed, all occurring in core 3 .

Deformed bedding (Fig. 8b) is very common in core 1 (4 observations) but rare in core 2 ( 1 observation) and absent in core 3. The deformed sandy beds usually occur immediately above or below a scoured surface or below a fine-grained bed (very fine sandstone or facies F). Some of the structures resemble water escape structures whereas others resemble convolute bedding. The deformations reflect liquefaction and pore-water expulsure and indicate high sedimentation rates (Middleton \& Hampton 1976, Allen 1977). Massive beds (5 observations) probably formed in a similar manner (cf. Middleton \& Hampton 1976).

\section{Facies organization and depositional environment}

The facies distribution in the three coreintervals is shown in table 1 . The most remarkable features are the dominance of facies $\mathrm{Sp}$ in all the cores, the abundance of facies St in core 2, the presence of extraformational clasts and frequency of facies Sh/l in core 3 and the scarcity of facies $\mathrm{F}$ in core 2 . In the following each core will be examined in more detail in respect to the facies distribution and sequences. 
Table 1. Facies distribution (\%)

\begin{tabular}{|l|c|c|c|c|}
\hline Facies & Core 1 & Core 2 & Core 3 & Total \\
\hline Sp & 51 & 54 & 50 & 51 \\
St & 20 & 31 & 14 & 22 \\
Sh & 2 & 8 & 27 & 15 \\
Sr & 6 & 7 & 3 & 5 \\
F & 13 & $<1$ & 6 & 4 \\
\hline
\end{tabular}

Core $3 ; 3152,2 m-3170,3 m$

Core 3 is characterized by an apparently unsystematic interbedding of facies types (Fig. 9). This feature combined with the dominance of facies $\mathrm{Sp}$ seem to indicate a Platte-type braided stream origin (cf. Smith
1970, 1971, Collinson 1970, Miall 1977, Blodgett \& Stanley 1980, Crowley 1983). This type of braided stream is characterized by low relief bed topography $(<3 \mathrm{~m})$ and a dominance of linguoid bars (Fig. 11a). Deeper channels, which tend to be occupied by trains of dunes, are only minor constituents of Platte-type streams (Miall 1985). Dunes are also superimposed on the top of linguoid bars (cf. Collinson 1970, Crowley 1983) but the preservation potential of these dune deposits is considered low. This probably explains why facies St is much less common than facies Sp in core 3 and when this facies occurs it tends to form cosets.

Facies $\mathrm{Sh} / \mathrm{l}$ and facies $\mathrm{F}$ are supposed to represent floodplain deposits, the former
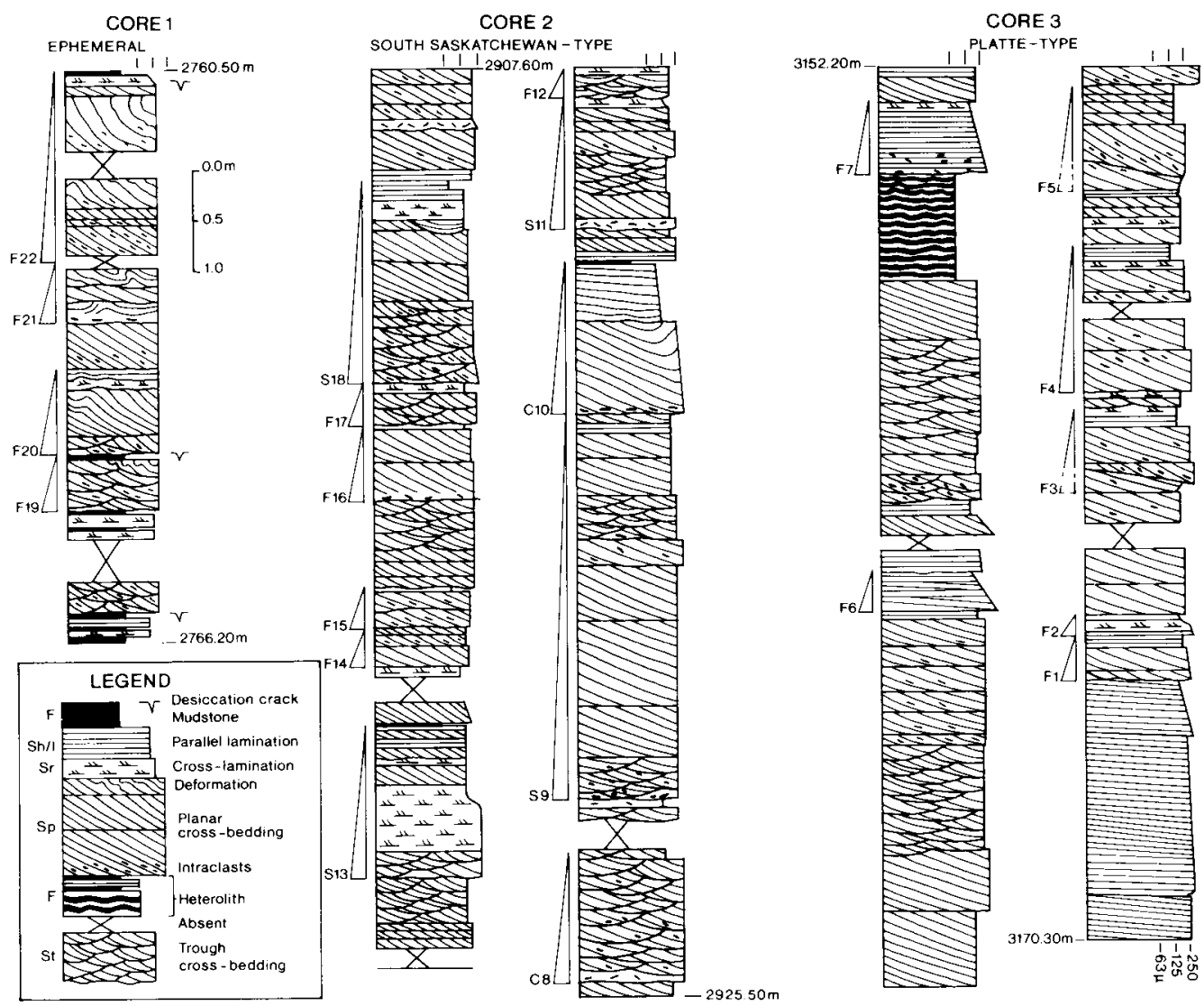

Fig. 9. Facies logs from the three cores in Skagerrak Formation, Thisted 2. Sedimentation units, which are generally fining-upwards, are indicated. F: flood controlled sedimentation unit. S: sand flat sequence. C: channel fill sequence. Core 1 is interpreted as ephemeral stream deposits, core 2 as South Saskatchewan-type deposits and core 3 as Platte-type deposits. 
being laid down close to the channels, the latter being deposited in more sheltered parts of the floodplain.

Characteristic facies sequences are not developed in core 3 . A number of thin $(<1.5 \mathrm{~m})$ fining upward sequences are, however, recognized (lettered $F$ in Fig. 9). These sequences are supposed to reflect individual flood episodes. Depending on the interpretation of the internal discordancies these surfaces are included (cf. Jones 1977) or form the base of the sequences (reactiva-

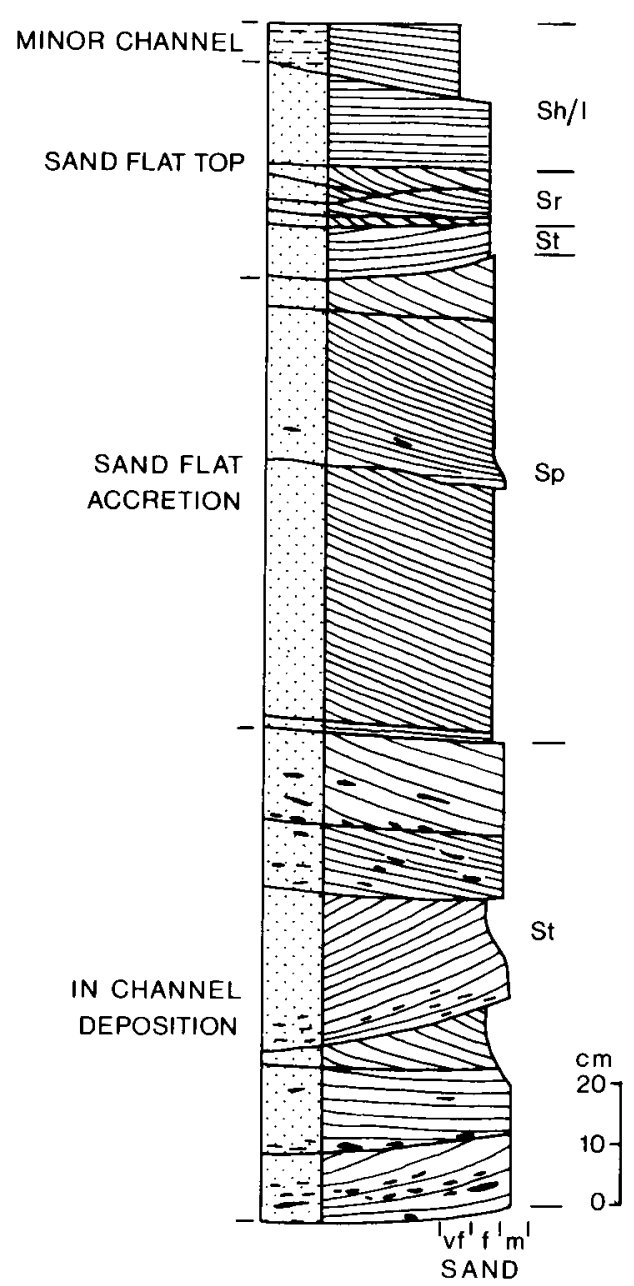

Fig. 10. Sand flat sequence (S18 from Fig. 9). The sequence reflects the development of a sand flat similar to the sand flat construction in the South Saskatchewan River (cf. Cant \& Walker 1978). tion surfaces, cf. Collinson 1970, MgGowen \& Groat 1971) in sequence F3 and F5 (Fig. 9).

\section{Core 2; 2907,6 m-2925,5 m}

The sediments in core 2 are characterized by an abundance of fining upward sequences (Fig. 9). By comparison with the hypothetical sequences erected by Cant and Walker (1978) for the South Saskatchewan River three sequence types can be distinguished, a sand flat type (S), a channel type (C) and a flood controlled type (F).

Type $S$ is most completely represented by S18 (Fig. 10). Trough cross-bedded channel deposits are here overlain by a coset of planar cross-sets, which probably reflect the growth of a sand flat by superimposed bars. Facies St, Sr and Sh/l represent the finer grained sand flat top deposits, which constitute the final stage of sand flat development and associated dissection by minor channels. In sequence $S 9$ (Fig. 9) the sand flat deposits (cosets of $\mathrm{Sp}$ ) have been cut by a small channel floored by dunes (facies $\mathrm{St}$ ). The sand flat has, however, subsequently been reestablished (upper Sp coset and Sh interbed), though sand flat top deposits are not preserved.

Sequence type $C$ differs from type $S$ in the absence of facies $\mathrm{Sp}$ cosets and thus indicates that sand flat development did not take place. Sequence C8 reflect channel aggradation entirely by dunes (facies $\mathrm{St}$ ). In contrast sequence $\mathrm{C} 10$ reflects the migration of a linguoid bar in a newly established channel and subsequent channel abandonment (fining upward $\mathrm{Sh} / \mathrm{l}$ channer fill).

The third sequence type (F) is fining upwards on a very small scale $(<1 \mathrm{~m})$ and is interpreted in terms of flood controlled sedimentation.

The sediments in core 2 reflect a high relief topography (channel incision) compared to core 3 (Fig. 11b). The thickness of individual sequences of type $\mathrm{S}$ and $\mathrm{C}$ is an estimate of the minimum relief, which ac- 
cordingly was in the range of $1.5 \mathrm{~m}$ to 3.75 $\mathrm{m}$. Relatively deep dune floored channels were therefore rather common and facies St thus occur more frequently than in core 3 .

\section{Core 1; 2760,5 m-2766,2 m}

The sediments of core 1 differ from those of core 2 and 3 mainly by their finer grain-size the abundance of facies $F$ and the frequency of soft sediment deformations. Four sequences have been identified in core 1 (Fig. 9). These sequences are characterized by an intraclast-strewn scoured base overlain by cross-bedded sand (facies Sp or St) and a thin cap of facies Sr and Sh or F. A significant feature is the occurrence of deformation structures near the top of all the sequences. In sequence F21 the base also exhibits soft sediment deformation. Noteworthy is also the presence of desiccation cracks in the mudstone beds.

The fining upward sequences in core 1 are interpreted as individual flood deposits. Desiccated mudstone cappings are definite signs of subaerial exposure of the stream bed. The frequency of desiccated mudstones therefore indicates that the discharge was more ephemeral than recorded from core 2 and 3 . The deformation structures may in this context be interpreted as formed due to rapid discharge changes. A rapid fall of discharge at the recession of a flood can result in high rates of sedimentation and consequently liquefaction of the falling stage deposits. Such falling stage deformations have previously been described from the Bijou Creek 1965 flood deposits by McKee et al. (1967). Rapid channel cutting and sediment dumping is supposed to have initiated the deformation of the lower part of sequence F21. Core 1 is interpreted as representing the model 11 of Miall (1985), the distal braidplain, where ephemeral runoff forms a network of shallow, interlacing, poorly defined channels (Fig. 11c). Modern examples have been described by Williams (1971), Karcz (1972) and Sneh (1983). The broad coarsening upwards and thickening upwards of sequences in core 1 may reflect the progradation of a segment of the braidplain. 


\section{The sandy braidplain environment}

Huge braidplains are not developed on the present day earth surface, probably due to the effect of increased vegetation cover, especially the appearance of grasses (cf. Schumm 1968). Direct analogies can therefore not be found. Braidplains are, however, traditionally interpreted to change characteristics in a downcurrent direction. The three types of braidplain sedimentation reflected by the three core intervals (Fig. 11) may therefore reflect the downcurrent change of the Skagerrak Formation sandy braidplain.

The gross fining upwards from almost pure sandstones to interbedded sandstones and mudstones in the Skagerrak Formation (Plate 1) suggests a general retrogradation of the alluvial system. An upward change from proximal to distal deposits is accordingly suspected in the core material from core 3 (lowermost core interval) to core 1 . The Platte-type sediments in core 3 are therefore interpreted as proximal sandy braidplain deposits. The South Saskatchewan-type sediments in core 2 are interpreted as intermediate braidplain deposits whereas the ephemeral stream deposits in core 1 represent the distal braidplain environment. According to Miall (1985) the difference between Platte-type streams and South Saskatchewan-type streams may be caused by greater stage fluctuations in the latter type. This argument is applied to the Skagerrak Formation braidplain because great discharge variations are suspected in a transitional zone between proximal streams with constant high discharges (Platte-type) and true ephemeral streams in the distal part of the braidplain.

Previous work on the Skagerrak Forma- tion by Pedersen and Andersen (1980), on core material from the Mors- 1 and Gassum-1 well (Fig. 1), concluded that no cyclic facies sequences were developed after a test by Selley's (1970) method. It is, however, apparent from the published sections (Pedersen \& Andersen 1980, their Fig. 3) that fining upward sequences resting on mudclast strewn erosion surfaces are common in Gassum-1. The sequences are typically less than $1 \mathrm{~m}$ thick and usually exhibit upward transitions from large-scale cross-bedding to small-scale cross-lamination or parallel lamination. These sequences thus resemble the supposed flood controlled (ephemeral) sequences in core 1 , Thisted-2. In contrast Mors- 1 shows no systematic lithological or facies trends and is almost entirely composed of large-scale cross-bedding (Pedersen \& Andersen 1980, their Fig. 2). These sediments resemble the Platte-type deposits recognized in core 3 , Thisted-2.

The core material covers most of the Skagerrak Formation in Gassum-1 and is regarded as representative for the formation at Gassum. The downcurrent position of Gassum-1 (Fig. 1) suggests that these ephemeral stream sediments are distal braidplain deposits. The core material from Mors-1 probably correlates to core 3 in Thisted 2 (cf. Nielsen 1982). The distance between the two wells is $20 \mathrm{~km}$ and thus the similarity between the two wells is not surprising. It shows, however, that a specific part of the braidplain at a given time was dominated by one specific stream type. The interpretation of the three fluvial subtypes as representing downcurrent changes of the braidplain and not coexisting (within a lim- 

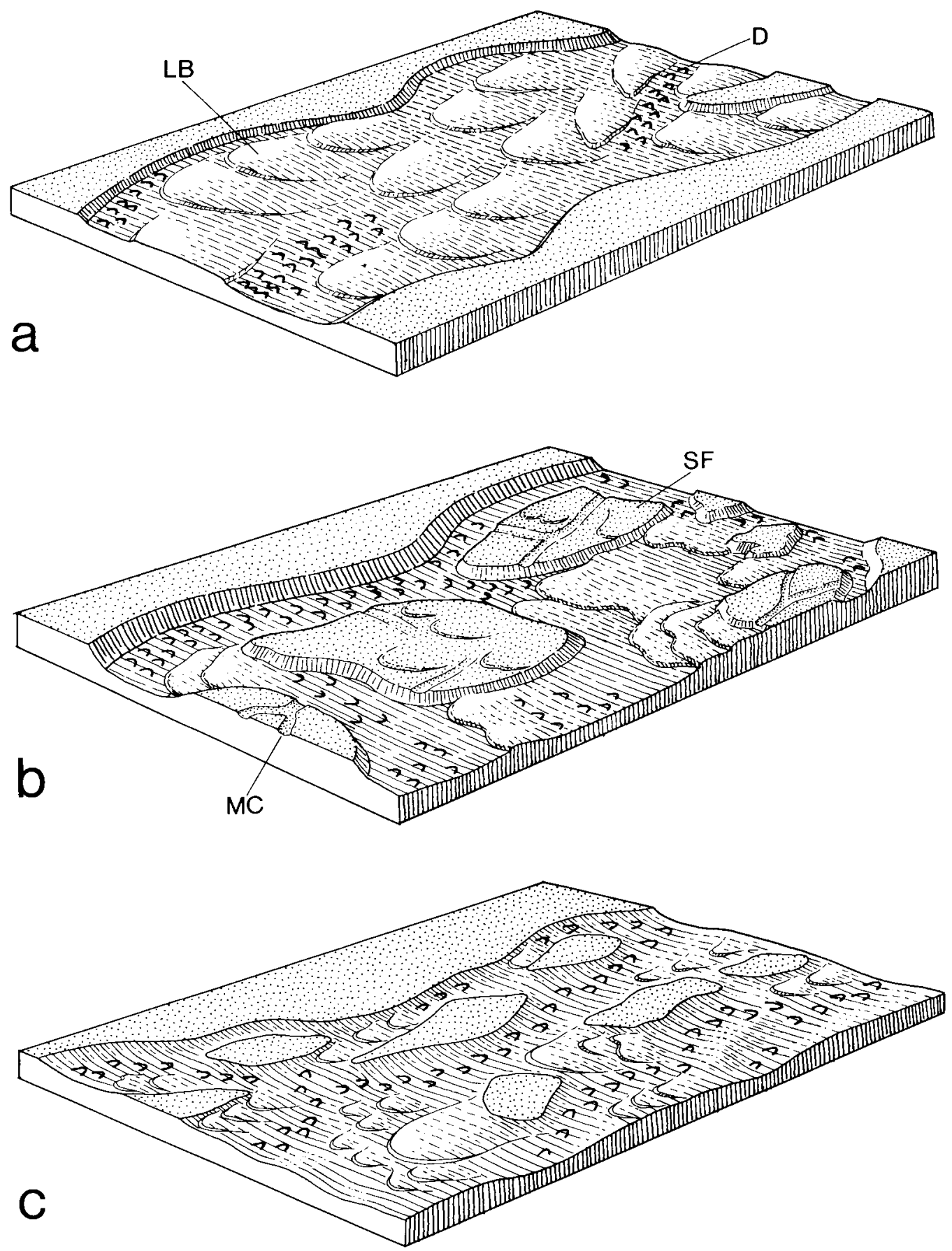

Fig. 11. Environmental reconstructions of the Skagerrak Formation sandy braidplain. (a) proximal braidplain with Platte-type streams. (b) intermediate braidplain with South Saskatchewan-type streams. (c) distal braidplain with ephemeral streams. LB: linguoid bars. D: dunes. SF: sand flat. MC: minor channel on sand flat. Flow is towards left. (Modified after Miall 1985). 
ited area) subenvironments seems therefore justified.

According to Bertelsen (1980) interbedded conglomerates, sandstones and mudstones in the northernmost Jutlandian wells (Skagen-2, Frederikshavn-1, -2, -3) and in Skåne, Sweden (Kågeröd beds) are included in the Skagerrak Formation. These sediments probably represent deposition on alluvial fans and may thus represent the marginal part of the Triassic palaeoenvironment.
The Skagerrak Formation in Denmark and Sweden thus represents an alluvial depositional environment with conglomeratic alluvial fans along the Fennoscandian Border Zone. Southwestwards the alluvial fans graded into sandy braidplains with distinct downcurrent changes from Platte-type streams to South Saskatchewan-type streams and finally ephemeral streams. 


\section{Depositional history}

The Skagerrak Formation is Scythian (early Triassic) to Norian (late Triassic) in age when fully developed (Bertelsen 1980). In early Triassic time the formation had its maximum southwestward extension and passed gradually into the Bunter Sandstone Formation (Bertelsen 1980). In southern Jutland (Tønder) the Bunter Sandstone Formation is dominated by ephemeral stream, aeolian sandsheet and sabkha deposits (Clemmensen 1985, Olsen 1987). The ephemeral stream deposits were laid down on terminal fans which represented the distal continuation of the Skagerrak Formation braidplain (Olsen 1987). During middle Triassic time the sandy braidplain gradually retrograded towards northeast while in late Triassic time a rapid displacement of the Skagerrak Formation facies belts towards north and east occurred (Bertelsen 1980). The displacement of facies belts was accompanied by an overstepping of the Fennoscandian Border Zone while a hypersaline basin was developed towards southwest (Bertelsen 1980).

The gradual upward change from Plattetype through South Saskatchewan-type to ephemeral stream deposits in the Thisted-2 well may be combined with the gradual retrogradation of the Skagerrak Formation in early to middle Triassic time. The gradual retrogradation could result from low subsidence rate in the basin and slow degradation of the source area. The upward change to interbedded sandstones and mudstones in Thisted-2 may be combined with the displacement of facies belts in the late Triassic. 


\section{Conclusions}

The Skagerrak Formation in North Jutland was laid down on a huge braidplain, sourced from the Fennoscandian Shield in the north and northeast. The braidplain was linked to a marginal coalescing alluvial fan environment towards the north and northeast. The braidplain thus formed the major basinal part of the Triassic continental palaeoenvironment in the eastern part of the Norwegian-Danish Basin. The proximal sandy braidplain was composed of shallow Plattetype streams. The intermediate part of the braidplain was dominated by deeper South Saskatchewan-type streams while the distal braidplain was composed of shallow ephemeral streams. The Skagerrak Formation in Thisted-2 probably reflects a gradual retrogradation of the braidplain through early to middle Triassic time followed by a rapid retrogradation in late Triassic time associated with overstepping of the Fennoscandian Border Zone.

\section{Acknowledgements}

The study was funded by the Danish Ministry for Energy to which my best thanks are directed. DOPAS A/S is greatly acknowledged for placing core material and petrophysical logs at my disposal. The paper is part of a lic.scient. study supervised by L.B.Clemmensen. Technical assistance by P.Andersen, O.B.Berthelsen, B.Damgaard, B.S.Hansen, J.Lautrup and R.Madsen is greatly acknowledged. The manuscript benefitted from critical reviews by L.B.Clemmensen, L.H.Nielsen, G.Krarup Pedersen and S.Stouge to whom my best thanks are directed. 


\section{References}

Allen, J.R.L., 1977: The possible mechanics of convolute lamination in graded sand beds. J.Geol.Soc.Lond.34, 19-31.

Allen, J.R.L., 1982: Sedimentary structures: their character and physical basis: Developments in sedimentology No. 30B. Elsevier, Amsterdam, $663 \mathrm{pp}$.

Bertelsen, F., 1980: Lithostratigraphy and depositional history of the Danish Triassic. Danmarks Geologiske Undersøgelse, Serie B, 4, København.

Blodgett, R.H. \& Stanley, K.O., 1980: Stratification, bedforms, and discharge relations of the Platte braided river system, Nebraska. J.Sed.Petr. 50, 139-148.

Bridge, J.S., 1978: Origin of horizontal lamination under turbulent boundary layers. Sed.Geology 20, 1-16.

Cant, D.J. \& Walker, R.G., 1978: Fluvial processes and facies sequences in the sandy braided South Saskatchewan River, Canada. Sedimentology 25, 625-648.

Cheel, R.J. \& Middleton, G.V., 1986: Horizontal laminae formed under upper flow regime plane bed conditions. J.Geology 94, 489-504.

Clemmensen, L.B., 1985: Desert sand plain and sabkha deposits from the Bunter Sandstone Formation (L.Triassic) at the northern margin of the German Basin. Geologische Rundschau 74, 519536.

Collinson, J.D., 1970: Bedforms of the Tana River, Norway. Geografiska Annaler 51A, 31-56.

Crowley, K.D., 1983: Large-scale bed configurations (macroforms), Platte River Basin, Colorado and Nebraska: Primary structures and formative processes. Bull.Geol.Soc.Am. 94, 117-133.

Deegan, C.E. \& Scull, B.J. (compilers) 1977: A proposed standard lithostratigraphic nomenclature for the Central and Northern North Sea. Rep.Inst.Geol.Sci. No. 77/25, 36 pp.

Frandsen, N., 1983: Thisted-2 Summary Report. Internal report, DGU.

Gustavson, T.C., Ashley, G.M. \& Boothroyd, J.C., 1975: Depositional sequences in glaciolacustrine deltas. In: Glaciofluvial and lacustrine sedimentation. Soc.Econ. Paleont.Miner., Spec.Publ. no. $23,264-280$.
Harms, J.C., 1975: Stratification produced by migrating bedforms. In: Depositional sedimentary structures and stratification sequences. Soc.Econ.Paleont.Miner., Short course no. 2, Dallas, 45-62.

Harms, J.C. \& Fahnestock, R.K., 1965: Stratification, bed forms and flow phenomena (with an example from Rio Grande). In: Middleton, G.V., ed., Primary Sedimentary Structures and their Hydrodynamic Interpretation: Soc.Econ.Paleont.Miner. Spec.Publ. No.2, 84-115.

Harms, J.C., Southard, J.D. \& Walker, R.G., 1982: Structures and sequences in clastic rocks. SEPM short course no. 9. Soc.Econ.Paleont.Miner., Calgary, 2-1-3-51.

Hunter, R.E., 1973: Pseudo-crosslamination formed by climbing adhesion ripples. J.Sed.Petr. 43, 1125-1127.

Hunter, R.E., 1980: Quasi-planar adhesion stratification-an eolian structure formed in wet sand. J.Sed.Petr. 50, 263-266.

Hunter, R.E., 1985: Subaqueous sand-flow cross strata. J.Sed. Petr. 55, 886-894.

Hunter, R.E. \& Kocurek, G., 1986: An experimental study of subaqueous slipface deposition. J.Sed.Petr. 55, 387-394.

Jackson, R.G., 1975: Hierarchical attributes and a unifying model of bed forms composed of cohesionless material and produced by shearing flow. Bull.Geol.Soc. Am. 86, 1523-1533.

Jakobsen, K.H., Hamar, G.P., Ormaasen, O.E. \& Skarpnes, O., 1980: Triassic facies in the North Sea north of the Central Highs. N.P.F. The sedimentation of the North Sea Reservoir Rocks. Geilo, XVIII, 1-10.

Jones, C.M., 1977: Effects of varying discharge requires on bed-form sedimentary structures in modern rivers. Geology 5, 567-570.

Jopling, A.V., 1965: Hydraulic factors controlling the shape of laminae in laboratory deltas. Jour.Sedim.Petrol. 35, 777-791.

Karcz, I., 1972: Sedimentary structures formed by flash floods in southern Israel. Sedimentary Geology $7,161-182$.

Kocurek, G. \& Fielder, G.982: Adhesion structures. J.Sed. Petr. 52, 1229-1241. 
McGowen, J.H. \& Groat, C.G., 1971: Van Horn Sandstone, West Texas: an alluvial fan model for mineral exploration. Report of investigations $v$. 72 , p. 57. Bureau of Economic Geology, Univ. of Texas, Austin.

McKee, E.D., Crosby, E.J. \& Berryhill, H.L., 1967: Flood deposits, Bijou Creek, Colorado. June 1965. Jour.Sediment.Petrol. 37, 829-851.

Miall, A.D., 1977: A review of the braided river depositional environment. Earth-Science Review v.3, 1-62.

Miall, A.D., 1985: Architectural-element analysis: A new method of facies analysis applied to fluvial deposits. Earth-Science Reviews 22, 261-308.

Middleton, G.V. \& Hampton, M.A., 1976: Subaqueous sediment transport and deposition by sediment gravity flows. In: Stanley, D.J. \& Swift, D.J.P., eds, Marine sediment transport and environmental management, Wiley-Intersci.Publ. New York, 197-218.

Nielsen, B.L., 1982: Thisted-2. Comment on the Triassic lithostratigraphic nomenclature. Internal report, D.O.N.G.

Olsen, H., 1987: Ancient ephemeral stream deposits: a local terminal fan model from the Bunter Sandstone Formation (L.Triassic) in the Tønder-3, -4 and -5 wells, Denmark. In: Frostick, L. \& Reid, I., eds, Desert sediments: Ancient and modern. Special publication of the Geological Society of London no 35, 69-86.
Pedersen, G.K. \& Andersen, P.R., 1980: Depositional environments, diagenetic history and source areas of some Bunter Sandstones in northern Jutland. Danmarks Geologiske Undersøgelse, Årbog 1979, 69-93.

Reineck, H-E. \& Singh, I.B., 1980: Depositional sedimentary environments. With reference to Terrigenous clastics. Springer-Verlag, Berlin, Heidelberg, New York, p. 549.

Schumm, S.A., 1968: Speculations concerning paleohydrologic controls of terrestrial sedimentation. Bull.geol.Soc.Am. 79, 1573-1588.

Selley, R.C., 1970: Studies of sequences in sediments using a simple mathematical device. Q.Jl.geol.Soc.Lond. 125, 557-581.

Smith, N.D., 1970: The braided stream depositional environment: Comparison of the Platte river with some Silurian clastic rocks, north-central Appalachians. Bull.Geol.Soc.Am. 81, 2992-3014.

Smith, N.D., 1971: Transverse bars and braiding in the lower Platte River, Nebraska. Bull.Geol.Soc. Am. 82, 3407-3420.

Sneh, A., 1983: Desert stream sequences in the Sinaj Peninsula. Journal of Sedimentary Petrology $53,1271-1279$.

Williams, G.E., 1971: Flood deposits of the sandbed ephemeral streams of central Australia. Sedimentology 17, 1-40. 

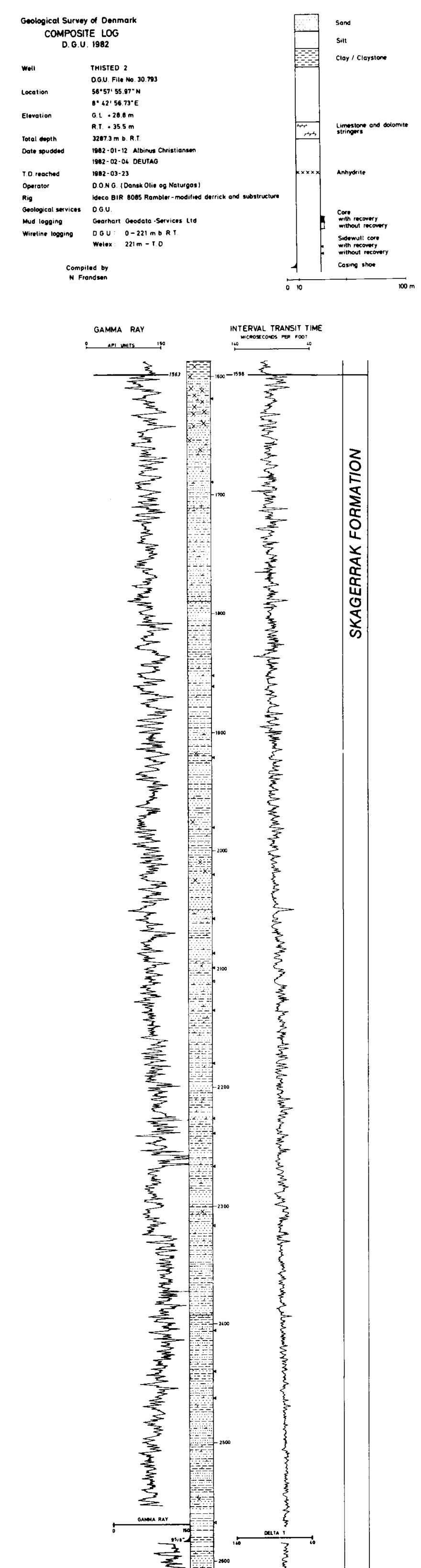
This paper presents a detailed facies analysis

of core material from the Triassic Skagerrak Formation

in the Thisted-2 well in northern Denmark

(the Danish Norwegian Basin) including a proposal

for a braidplain model for the depositional environment. 